\title{
THE DEVELOPMENT EFFECTS OF THE MONETARY AND FISCAL POLICY IN CONTEMPORARY CONDITIONS
}

\author{
UDC 336.02
}

$338.23: 336.74$

\section{Danijel Milošević*, Vladislav Marjanović}

University of Niš, Faculty of Economics, Niš, Serbia

\begin{abstract}
One of the biggest problems in economic theory has always been coordination of different elements of economic policy, especially monetary and fiscal policy. In the past, there have been a few theories emphasizing one of them, but in contemporary conditions it is a fact that the only right answer is in coordinated conducting of all of them. Therefore, every measure in monetary policy has to be followed by particular action in fiscal policy and the other way around. The question remains whether fiscal or monetary policy should have the priority in decision making and is there a pattern to follow when it comes to creating economic policy. Empirical data are the most purposeful source for answering these questions, and therefore we will use variables from four different countries from the last fifteen years and try to find the connection between monetary and fiscal policy and the standard of living.
\end{abstract}

Key words: Economic policy, Monetary policy, Fiscal policy

JEL Classification: E52, E62

\section{INTRODUCTION}

It seems that the world has not managed to propel economic activity since the last economic crisis of 2008, and that the demand is still very low. What has led to this is a combination of economic and political factors. First of all, terrorist attacks, which have represented the Sisyphus's boulder since the beginning of the twenty-first century, have made business and political risks extremely high. Secondly, banking systems all over the world need more time to build the trust they had before the crisis. Thirdly, the new

Received March 26, 2018 / Revised June 27, 2018 / Revised September 27, 2018 / Accepted October 15, 2018 Corresponding author: Danijel Milošević

* PhD student at University of Niš, Faculty of Economics

Faculty of Economics Niš, Trg kralja Aleksandra 11, 18000 Niš, Serbia

E-mail: danijel.m1989@gmail.com 
technological revolution is getting more and more intense and creating high structural unemployment, which will, almost certainly, last for a few more years. Japan has been on the top of the production function for almost twenty years now, and they still cannot find a way to move it upwards. America seems blinded by politics, and deals little with economics. Russia is struggling with the EU sanctions, and the rest of the world is struggling with, in the words of the Nobel Prize winner, Joseph Stiglitz, globalization and its discontents. Only China keeps positive trends in every single parameter, which is not surprising, having in mind that China entered the global flows very carefully and under its own conditions. On the other hand, no other country has had enough power to do the same.

The usual recipe in similar situations is a cheap money policy, which should drive the money out of the banks, and make people and firms invest, finally propelling economic activity. However, a cheap money policy has already been led in most parts of the world since the end of the last crisis, but without any results. Demand has not reacted. In today's neoliberal world, it would be extremely difficult to admit that Keynes was right, and that the states would have to do their parts in getting out of the crisis. Whether that will be a necessity, or whether the market will eventually find its way out, only time will tell. The hypothesis that we will try to prove or confute is that the fiscal policy will have to bear the brunt in contemporary conditions.

\section{Methodology}

Having in mind that structural unemployment is a very serious issue today, not only in underdeveloped and developing countries, but also in some developed ones, GDP (even GDP per capita) is no longer a fair representative of development in certain countries. Therefore, the main parameter in this research, which is also a dependent variable, is the GDP/Unemployment rate of workforce. Monetary aggregate M2 and interest rate, as representatives of monetary policy, and government expenditures, as a representative of fiscal policy, will be independent variables. We will take into consideration twelve randomly picked countries (an equal number of developing and developed countries), and the data from 2000 to 2015 . These twelve countries are firstly grouped in four categories regarding the GDP/Unemployment rate of the workforce, using the cluster analysis, after which we chose one from each cluster, and then, using multiple regression, the contribution to a dependent variable is determined for every independent variable.

\section{COMPLEMENTARY ACTION OF FISCAL AND MONETARY POLICY}

It is clear that in today's dynamic conditions, it is impossible to exclusively use recommendations of the certain schools of economic policy, as was the case in the twentieth century. Therefore, a coordinated management of all elements of economic policy, and especially the monetary and fiscal policy, is a necessity. The most important reason for this is that these two policies have clear effects on one another. It is impossible to correct the fiscal policy without repercussions on the aggregates of monetary policy, or the other way around.

With its action, the fiscal policy can upset the monetary one (Sergent, Wallace, 1981). Some potential manifestations of this interference are that, in conditions of low fiscal space, an expansive fiscal policy may create a budget deficit, which undoubtedly affects the 
monetary policy. In case the government decides to monetize the budget deficit, both the monetary and fiscal policies become expansive, which is allowed only during serious recessions, and only for a short period of time. In other cases, the effect is entering an inflationary spiral. Another option for the government is to finance the deficit by public debt, which is also a trigger for inflation, through the exchange rate (Campillo, Miron, 1997). Even a restrictive fiscal policy, or raising taxes, can lead to inflation, because of the prices' sensitivity to costs.

Monetary policy can also upset fiscal policy (Beetsma, Bovenberg, 1998, 1999). Interest rates are one of the main factors of accumulation and investments, and therefore, production. Besides that, interest rates have a huge significance in financing public debt. Inflation too has a significant effect on public finances. There is a rule in economic theory, known as the Tanzi effect, which states that, during hyperinflation, taxes are completely insignificant because of the time lag between the moment of the formation of a tax obligation, and the moment of the execution of a tax obligation (Tanzi, 1977). During this time lag, money loses its value, and the government loses tax revenue. This is exactly the reason why inflation is the primary target in most central banks today.

It is, therefore, not the question which of the policies the government will use for creating a desirable economic environment, but only which one will be accentuated, and that automatically produces the need for creating a coordinated strategy for the other one. In order to coordinate these policies successfully, and to correctly anticipate all the effects of every undertaken measure, one needs to know all the repercussions of the two policies on one another (Delong, Summers, Feldstein and Ramey, 2012). Creating a coordinated fiscal and monetary policy, taking into consideration that their goals are sometimes opposite, is in fact the game theory, and the ultimate goal is to maximize the summed gain. For this to work, it is necessary to institutionally regulate relations between the subjects of both monetary and fiscal policy, for without that, it is very optimistic to expect that they are going to see the big picture. Every one of them will stay focused on their own goals, and the summed gain will be unsatisfactory. The government will worry only about the budget, and the central bank will worry only about inflation, as long as their relations are not regulated. The key lies in the fact that, even though they are limiting factors to one another in a tight perspective, in the long term, it is only possible to achieve stable growth with low inflation, and an ultimately high living standard, by coordinately managing both monetary and fiscal policy.

\section{THE MONETARY AND FISCAL POLICIES' INFLUENCE ON THE ECONOMIC DEVELOPMENT OF SELECTED COUNTRIES ${ }^{2}$}

Based on the data about the fiscal and monetary policy in the twelve selected countries, from year 2000 to 2015, as well as the results measured by the ratio between the GDP and the unemployment rate of the workforce in the same period, we will search for the connection between these two, and the answer to the question as to what extent certain elements of the mentioned policies have influenced the achieved results. We will use multiple regression, with a simultaneous inclusion of all independent variables into the

\footnotetext{
${ }^{2}$ In this section we used Soldić-Aleksić J. (2011). Primenjena Analiza Podataka, Ekonomski fakultet u Beogradu, pp. 186-239.
} 
model, while conducting the influence of independent variables on the dependent variable on the hierarchical scale. Independent variables are government expenditure, representing fiscal policy, and monetary aggregate M2 and interest rate, representing monetary policy, and the dependent variable is the GDP/Unemployment rate of workforce ratio.

The result of the cluster analysis are four groups of countries regarding two parameters: GDP and unemployment of the workforce. That is a step in creating a purposive stratified sample by taking one country from every cluster, in order to avoid the analysis of only countries similar to each other. We chose to do multiple regression on the USA, Serbia, Germany and China. The standard error $-\alpha$, is set on $5 \%$, or 0.05 . Zero hypothesis $-\mathrm{H} 0$ is: There are no connections between the independent variables and the dependent one; the first hypothesis $-\mathrm{H} 1$ is: there is a connection between at least one of the independent variables and the dependent one.

\subsection{Multiple regression - The USA}

The Correlations table (Table 1) shows the Pearson correlation, Significance and number of years which we took into consideration. The Pearson correlation indicates the strength of the connection between the data, and it varies from -1 to 1 , where -1 is the least strong relation, and 1 is, obviously, the strongest one. The third row of the table shows the Significance, which, if smaller than the risk of error, in this case 0.05 , means that we dismiss the zero hypothesis, H0: There is no connection between the independent and the dependent variable; and accept the first hypothesis, H1: There is a significant connection between the independent and the dependent variable. As we can see, only the significance for the interest rate is lower than 0.05 , but for the other two independent variables, there is a significant connection, and we, therefore, accept the first hypothesis, i.e. that there is a significant connection between at least one independent variable and the dependent one.

Table 1 Correlations between independent and dependent variables in the USA

\begin{tabular}{llc}
\hline & & GDP/Unemployment \\
\hline Pearson Correlation & Government Expenditures & .022 \\
& M2 & .173 \\
& Interest Rate & .449 \\
\hline Sig. (1-tailed) & Government Expenditures & .468 \\
& M2 & .261 \\
& Interest Rate & .040 \\
\hline $\mathrm{N}$ & & 16 \\
\hline
\end{tabular}

Table 2 shows that the multiple correlation coefficient $-\mathrm{R}$ equals 0.787 , which indicates a very strong correlation between the independent and the dependent variable. The determination coefficient $-R^{2}$ equals 0.619 , which tells us that $61.9 \%$ of the variability of the GDP/Unemployment ratio is explained by the model. The adjusted determination coefficient takes into account the number of independent variables and the number of observations. The big difference between the adjusted and the simple determination coefficient indicates that we have a relatively small number of observations -16 , and that the model would be more valid with more observations. Considering that we are doing the same research using data from four countries, we will still try to draw some conclusions based on fewer observations. 
Testing of the statistical validity or justification of using particular variables is done by, among others, F statistics:

$$
F=\frac{\mathrm{R}_{2}^{2}-R_{1}^{2}}{1-R_{2}^{2}} \frac{d_{2}}{d_{1}-d_{2}}
$$

In this iteration, $R_{2}^{2}$ and $R_{1}^{2}$ are determination coefficients using higher and lower number of variables and $d_{2}$ and $d_{1}$ are corresponding levels of freedom. The difference between $R_{2}^{2}$ and $R_{1}^{2}$ is $\mathrm{R}$ Square Change.

Table 2 Model summary statistics, the USA

\begin{tabular}{|c|c|c|c|c|c|c|c|c|c|c|}
\hline \multirow[b]{2}{*}{ Model } & \multirow[b]{2}{*}{$\mathrm{R}$} & \multirow[b]{2}{*}{$\begin{array}{c}\mathrm{R} \\
\text { Square }\end{array}$} & \multirow[b]{2}{*}{$\begin{array}{l}\text { Adjusted } \\
\text { R Square }\end{array}$} & \multirow[b]{2}{*}{$\begin{array}{l}\text { Std. Error of } \\
\text { the Estimate }\end{array}$} & \multicolumn{5}{|c|}{ Change Statistics } & \multirow[b]{2}{*}{$\begin{array}{l}\text { Durbin- } \\
\text { Watson }\end{array}$} \\
\hline & & & & & $\begin{array}{c}\text { R Square } \\
\text { Change }\end{array}$ & $\begin{array}{c}\mathrm{F} \\
\text { Change }\end{array}$ & df1 & df2 & $\begin{array}{c}\text { Sig. F } \\
\text { Change }\end{array}$ & \\
\hline 1 & .787 & .619 & .524 & 3.86394E11 & .619 & 6.508 & 3 & 12 & .007 & 1.158 \\
\hline
\end{tabular}

For testing the assumptions of linear regression it is of great significance to follow the residuals. Assumptions are:

1. Normal distribution

2. Linearity

3. Heteroscedasticity

The fulfillment of these assumptions can be tested using Scatter plot (Fig. 1), which shows standardized values of dependent variable on an $\mathrm{X}$ axis and standardized residuals on a $\mathrm{Y}$ axis.

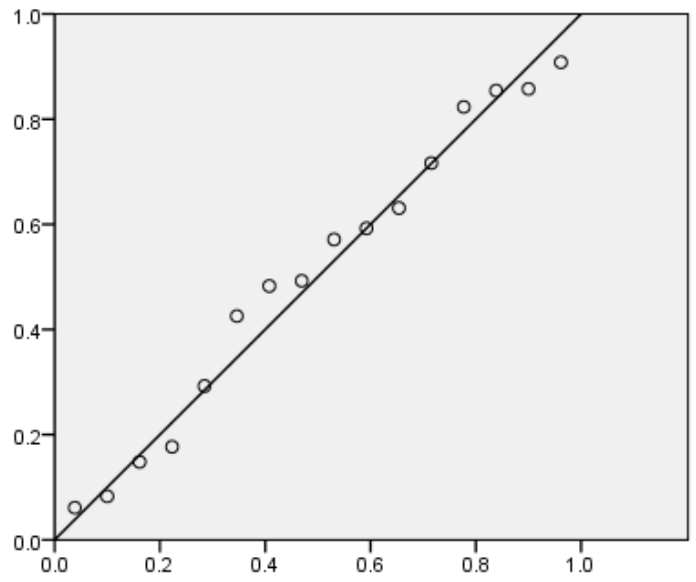

Fig. 1 Scatter Plot, dependent variable - GDP/Unemployment in the USA

In this analyzed case, Scatter Plot shows mostly sporadic deviations of standardized residuals from normal distribution on a $45^{\circ}$ line. This further proves the absence of heteroscedasticity of residuals and presence of only sporadic atypical dots. The same can be proved by a Histogram for analyzed dependable variable - GDP/Unemployment in the USA. Namely, the Histogram shows quite normal distribution of data. 


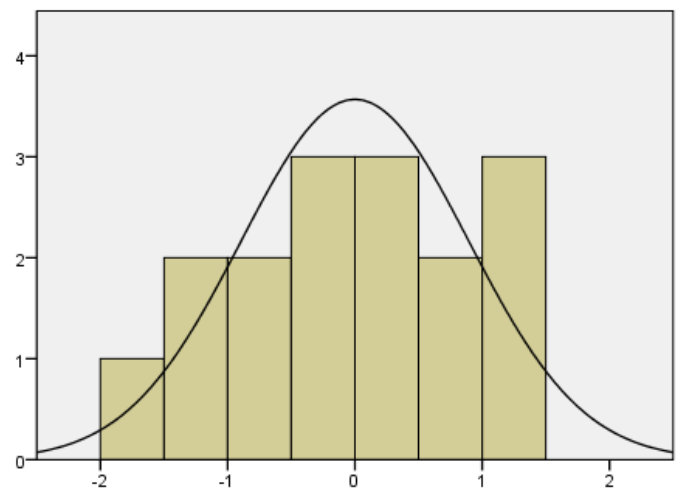

Fig. 2 Histogram for the dependent variable - GDP/Unemployment in the USA

Table 3 Testing the model for the USA, ANOVA ${ }^{\mathrm{b}}$

\begin{tabular}{ccccccc}
\hline & Model & Sum of Squares & df & Mean Square & F & Sig. \\
\hline \multirow{3}{*}{1} & Regression & $2.915 \mathrm{E} 24$ & 3 & $9.716 \mathrm{E} 23$ & 6.508 & $.007^{\mathrm{a}}$ \\
& Residual & $1.792 \mathrm{E} 24$ & 12 & $1.493 \mathrm{E} 23$ & & \\
Total & $4.706 \mathrm{E} 24$ & 15 & & \\
\hline \multicolumn{5}{c}{ a. Predictors: (Constant), Interest rate, Government expenditure, M2 } \\
b. Dependent Variable: GDP/Unemployment
\end{tabular}

The ANOVA (Analysis of Variance) procedure, showed in Table 3, tests the general validity of the model. The so-called F-test shows the correlation between the explained and the unexplained variability of the dependent variable. In this model, the F value of 6.508 and Sig. of 0,007 indicates that the determination coefficient is definitely different from zero.

Table 4 Coefficients of influence for independent variables, the USA

\begin{tabular}{ccccccc}
\hline \multirow{2}{*}{ Model } & \multicolumn{2}{c}{$\begin{array}{c}\text { Unstandardized } \\
\text { Coefficients }\end{array}$} & $\begin{array}{c}\text { Standardized } \\
\text { Coefficients }\end{array}$ & \multicolumn{2}{c}{$\begin{array}{c}\text { Collinearity Statistics } \\
\text { Tolerance }\end{array}$} & VIF \\
\cline { 2 - 4 } & \multicolumn{2}{c}{$\mathrm{B}$} & Std. Error & Beta & Toler & \\
& (Constant) & $1.248 \mathrm{E} 12$ & $7.903 \mathrm{E} 11$ & & & \\
1 & Government Expenditure & -.898 & .622 & $\mathbf{. 6 5 0}$ & .157 & 6.384 \\
& M2 & 321178.678 & 109822.016 & $\mathbf{1 . 3 3 7}$ & .152 & 6.585 \\
& Interest Rate & $2.363 \mathrm{E} 11$ & $6.130 \mathrm{E} 10$ & $\mathbf{. 8 9 5}$ & .589 & 1.699 \\
\hline
\end{tabular}

The Coefficients table is the most significant one for creating a model. In the second column of this table, there are B coefficients, which are usually used for representing the numerical influence of every independent variable. However, for our purposes, the Standardized Beta Coefficients (fourth column) are more suitable because they eliminate the effect of huge numerical differences between the expressions of independent variables on the model itself. Based on Table 8, we can create a model:

$$
\frac{G D P}{\text { Unemployment }}=1.248 .000 .000 .000-0,650 * E+1,337 * M 2+0,895 * i
$$


In this model (and further), -E- stand for Government Expenditures, M2 is clear and $i$ - is interest rate. In case of the USA, it is noticeable that monetary policy had higher contribution to GDP/Unemployment of workforce ratio. That means that the American economic policy is created in such a way that the monetary policy has a dominant role in achieving economic goals.

\subsection{Multiple regression - The Republic of Serbia}

The Pearson correlation indicates a very strong correlation between both government expenditures and M2 aggregate and the GDP/Unemployment ratio. Interest rate, however, does not affect the GDP/Unemployment so strongly. The third row of the table shows that all three independent variables have a Significance under 0.05 , which means that there is a significant connection between the independent and the dependent variable.

Table 5 Correlations between independent and dependent variables in Serbia

\begin{tabular}{llc}
\hline & & GDP/Unemployment \\
\hline Pearson Correlation & Government Expenditures & .891 \\
& M2 & .700 \\
& Interest Rate & -.563 \\
\hline Sig. (1-tailed) & Government Expenditures & .000 \\
& M2 & .001 \\
& Interest Rate & .012 \\
\hline $\mathrm{N}$ & & 16 \\
\hline
\end{tabular}

Table 6 Model summary statistics, Serbia

\begin{tabular}{|c|c|c|c|c|c|c|c|c|c|c|}
\hline \multirow[b]{2}{*}{ Model } & \multirow[b]{2}{*}{$\mathrm{R}$} & \multirow[b]{2}{*}{$\begin{array}{c}\mathrm{R} \\
\text { Square }\end{array}$} & \multirow[b]{2}{*}{$\begin{array}{l}\text { Adjusted } \\
\text { R Square }\end{array}$} & \multirow[b]{2}{*}{$\begin{array}{l}\text { Std. Error of } \\
\text { the Estimate }\end{array}$} & \multicolumn{5}{|c|}{ Change Statistics } & \multirow[b]{2}{*}{$\begin{array}{l}\text { Durbin- } \\
\text { Watson }\end{array}$} \\
\hline & & & & & $\begin{array}{c}\text { R Square } \\
\text { Change }\end{array}$ & $\begin{array}{c}\mathrm{F} \\
\text { Change }\end{array}$ & df1 & df2 & $\begin{array}{c}\text { Sig. F } \\
\text { Change }\end{array}$ & \\
\hline 1 & $.892^{\mathrm{a}}$ & .795 & .744 & $3.51673 \mathrm{E} 8$ & .795 & 15.528 & 3 & 12 & .000 & 1.104 \\
\hline
\end{tabular}

b. Dependent Variable: GDP/Unemployment

The adjusted determination coefficient shows that $74.4 \%$ of the dependent variable's variability is explained by the model, so the model is valid.

Table 7 Testing the model for Serbia, ANOVA ${ }^{\mathrm{b}}$

\begin{tabular}{ccccccc}
\hline & Model & Sum of Squares & df & Mean Square & F & Sig. \\
\hline \multirow{2}{*}{1} & Regression & $5.761 \mathrm{E} 18$ & 3 & $1.920 \mathrm{E} 18$ & 15.528 & $.000^{\mathrm{a}}$ \\
& Residual & $1.484 \mathrm{E} 18$ & 12 & $1.237 \mathrm{E} 17$ & & \\
& Total & $7.245 \mathrm{E} 18$ & 15 & & & \\
\hline
\end{tabular}

a. Predictors: (Constant), Interest rate, M2, Government expenditures

b. Dependent Variable: GDP/Unemployment

ANOVA confirms the validity of the model, because the explained part of variability is 15.528 times greater than the unexplained one, and Sig. is lower than 0.05. 
Table 8 Coefficients of influence for independent variables, Serbia

\begin{tabular}{ccccccc}
\hline \multirow{2}{*}{ Model } & \multicolumn{2}{c}{ Unstandardized Coefficients } & $\begin{array}{c}\text { Standardized } \\
\text { Coefficients }\end{array}$ & \multicolumn{2}{c}{ Collinearity Statistics } \\
\cline { 2 - 7 } & $\mathrm{B}$ & Std. Error & Beta & Tolerance & VIF \\
\hline (Constant) & $1.481 \mathrm{E} 8$ & $5.040 \mathrm{E} 8$ & & & \\
1 & Government Expenditure & .263 & .067 & $\mathbf{. 8 7 2}$ & .347 & 2.884 \\
M2 & 2.717 & 715.387 & $\mathbf{. 0 0 1}$ & .377 & 2.653 \\
& Interest Rate & -4314907.744 & $2.375 \mathrm{E} 7$ & $\mathbf{- . 0 3 0}$ & .608 & 1.644 \\
\hline
\end{tabular}

Based on the data from the Coefficients table, we create a model:

$$
\frac{G D P}{\text { Unemployment }}=148.100 .000+0,872 * E+0,001 * M 2-0,030 * i
$$

In the case of Serbia, the coefficient for government expenditure of 0.872 shows that fiscal policy had much higher contribution to GDP/Unemployment of workforce ratio than $M_{2}(0.001)$ and interest rate (0.030). Therefore, opposed to the USA, Serbia uses predominantly fiscal policy as an instrument for achieving economic goals.

\subsection{Multiple regression - The Federal Republic of Germany}

The Pearson correlation shows an extremely strong correlation between both government expenditures and M2 aggregate and the GDP/Unemployment ratio. The correlation between the interest rate and the GDP/Unemployment ratio is, however, extremely weak. The third row shows significance, which is lower than 0.05 for every independent variable. Therefore, there is a significant correlation between the independent and the dependent variable.

Table 9 Correlations between independent and dependent variables in Germany

\begin{tabular}{ccc}
\hline & & GDP/Unemployment \\
\hline \multirow{3}{*}{ Pearson Correlation } & Government Expenditures & .867 \\
& $\mathrm{M} 2$ & .976 \\
& Interest Rate & -.939 \\
\hline \multirow{2}{*}{ Sig. (1-tailed) } & Government Expenditures & .000 \\
& $\mathrm{M} 2$ & .000 \\
& Interest Rate & .000 \\
\hline $\mathrm{N}$ & & 16 \\
\hline
\end{tabular}

Table 10 Model summary statistics, Germany

\begin{tabular}{|c|c|c|c|c|c|c|c|c|c|c|}
\hline \multirow[b]{2}{*}{ Model } & \multirow[b]{2}{*}{$\mathrm{R}$} & \multirow[b]{2}{*}{$\begin{array}{c}\mathrm{R} \\
\text { Square }\end{array}$} & \multirow[b]{2}{*}{$\begin{array}{l}\text { Adjusted } \\
\text { R Square }\end{array}$} & \multirow[b]{2}{*}{$\begin{array}{l}\text { Std. Error of } \\
\text { the Estimate }\end{array}$} & \multicolumn{5}{|c|}{ Change Statistics } & \multirow[b]{2}{*}{$\begin{array}{l}\text { Durbin- } \\
\text { Watson }\end{array}$} \\
\hline & & & & & $\begin{array}{l}\text { R Square } \\
\text { Change }\end{array}$ & $\begin{array}{c}\mathrm{F} \\
\text { Change }\end{array}$ & df1 & df 2 & $\begin{array}{l}\text { Sig. F } \\
\text { Change }\end{array}$ & \\
\hline 1 & $.978^{\mathrm{a}}$ & 956 & .946 & $4.63988 \mathrm{E} 10$ & .956 & 87.948 & 3 & 12 & .000 & 1.311 \\
\hline
\end{tabular}

a. Predictors: (Constant), Interest rate, Government expenditures, M2

The adjusted determination coefficient indicates that $94.6 \%$ of the dependent variable's variability is explained with the model. This model explains the variability of the dependent variable very successfully. 
Table 11 Testing the model for Germany, ANOVA ${ }^{\mathrm{b}}$

\begin{tabular}{ccccccc}
\hline & Model & Sum of Squares & df & Mean Square & F & Sig. \\
\hline \multirow{3}{*}{1} & Regression & $5.680 \mathrm{E} 23$ & 3 & $1.893 \mathrm{E} 23$ & 87.948 & $.000^{\mathrm{a}}$ \\
& Residual & $2.583 \mathrm{E} 22$ & 12 & $2.153 \mathrm{E} 21$ & & \\
Total & $5.939 \mathrm{E} 23$ & 15 & & & \\
\hline \multicolumn{5}{c}{ a. Predictors: (Constant), Interest rate, Government expenditures, M2 } \\
& b. Dependent Variable: GDP/Unemployment
\end{tabular}

The F-test shows that the correlation between the explained and the unexplained part of the variability of the dependent variable is very good, and that the explained part is 87.948 times greater than the unexplained one.

Table 12 Coefficients of influence for independent variables, Germany

\begin{tabular}{ccccccc}
\hline \multirow{2}{*}{ Model } & \multicolumn{2}{c}{$\begin{array}{c}\text { Unstandardized } \\
\text { Coefficients }\end{array}$} & $\begin{array}{c}\text { Standardized } \\
\text { Coefficients }\end{array}$ & \multicolumn{2}{c}{ Collinearity Statistics } \\
\cline { 2 - 7 } & \multicolumn{2}{c}{$\mathrm{B}$} & Std. Error & Beta & Tolerance & VIF \\
\hline \multirow{4}{*}{1} & (Constant) & $-2.440 \mathrm{E} 11$ & $2.440 \mathrm{E} 11$ & & & \\
& Government Expenditure & .146 & .186 & $\mathbf{. 0 9 4}$ & .254 & 3.937 \\
& M2 & 368382.470 & 101726.159 & $\mathbf{. 7 8 6}$ & .077 & 12.990 \\
& Interest Rate & $-1.619 \mathrm{E} 10$ & $2.734 \mathrm{E} 10$ & $\mathbf{- . 1 1 5}$ & .097 & 10.360 \\
\hline
\end{tabular}

Based on the data from the Coefficients table, we create a model:

$$
\frac{G D P}{\text { Unemployment }}=-244.000 .000 .000+0,094 * E+0,786 * M 2-0,115 * i
$$

It is clear that monetary policy had higher influence on GDP/Unemployment of workforce ratio than fiscal policy in Germany. Namely, coefficients of 0.786 and 0.115 for the $M_{2}$ monetary aggregate and for the interest rate, in that order are higher than 0.094 - coefficient for the contribution of government expenditure to the GDP/Unemployment of workforce ratio.

\subsection{The multiple regression - The People's Republic of China}

The third column of the Correlations table shows us the influence of independent variables on the GDP/Unemployment ratio. The Pearson correlation indicates a very strong correlation between both government expenditures and M2 aggregate and the GDP/Unemployment ratio. The correlation between interest rate and the GDP/Unemployment ratio is not that strong. The third row of the table shows a significance which is lower than 0.05 for the independent variables of government expenditures and M2 aggregate. Therefore, correlation between the independent variables and the dependent one exists.

Table 13 Correlations between independent and dependent variables in China

\begin{tabular}{ccc}
\hline & & GDP/Unemployment \\
\hline Pearson Correlation & Government Expenditures & .999 \\
& $\mathrm{M} 2$ & .995 \\
& Interest Rate & .095 \\
\hline Sig. (1-tailed) & Government Expenditures & .000 \\
& $\mathrm{M} 2$ & .000 \\
$\mathrm{~N}$ & Interest Rate & .363 \\
\hline
\end{tabular}


Table 14 Model summary statistics, China

\begin{tabular}{|c|c|c|c|c|c|c|c|c|c|c|}
\hline \multirow[b]{2}{*}{ Model } & \multirow[b]{2}{*}{$\mathrm{R}$} & \multirow[b]{2}{*}{$\begin{array}{c}\mathrm{R} \\
\text { Square }\end{array}$} & \multirow[b]{2}{*}{$\begin{array}{l}\text { Adjusted } \\
\text { R Square }\end{array}$} & \multirow[b]{2}{*}{$\begin{array}{l}\text { Std. Error of } \\
\text { the Estimate }\end{array}$} & \multicolumn{5}{|c|}{ Change Statistics } & \multirow[b]{2}{*}{$\begin{array}{l}\text { Durbin- } \\
\text { Watson }\end{array}$} \\
\hline & & & & & $\begin{array}{c}\mathrm{R} \\
\text { Square } \\
\text { Change }\end{array}$ & F Change & df1 & df2 & $\begin{array}{l}\text { Sig. F } \\
\text { Change }\end{array}$ & \\
\hline 1 & $.999^{\mathrm{a}}$ & .999 & .999 & $3.26099 \mathrm{E} 10$ & .999 & 3360.763 & 3 & 12 & .000 & 1.457 \\
\hline
\end{tabular}

The adjusted determination coefficient tells us that an unbelievable $99.9 \%$ of the variability of the dependent variable is explained by the model. Therefore, the model explains the variability of the dependent variable successfully.

Table 15 Testing the model for China, ANOVA ${ }^{\mathrm{b}}$

\begin{tabular}{ccccccc}
\hline & Model & Sum of Squares & df & Mean Square & F & Sig. \\
\hline \multirow{4}{*}{1} & Regression & $1.072 \mathrm{E} 25$ & 3 & $3.574 \mathrm{E} 24$ & 3360.763 & $.000^{\mathrm{a}}$ \\
& Residual & $1.276 \mathrm{E} 22$ & 12 & $1.063 \mathrm{E} 21$ & & \\
& Total & $1.073 \mathrm{E} 25$ & 15 & & & \\
\hline
\end{tabular}

a. Predictors: (Constant), Interest rate, M2, Government expenditure

b. Dependent Variable: GDP/Unemployment

In this case, the explained part of the mentioned variability is 3360.763 times greater than the unexplained one, which undoubtedly confirms validity of the model.

Table 16 Coefficients of influence for independent variables, China

\begin{tabular}{ccccccc}
\hline \multirow{2}{*}{ Model } & \multicolumn{2}{c}{$\begin{array}{c}\text { Unstandardized } \\
\text { Coefficients }\end{array}$} & $\begin{array}{c}\text { Standardized } \\
\text { Coefficients }\end{array}$ & \multicolumn{2}{c}{ Collinearity Statistics } \\
\cline { 2 - 7 } & \multicolumn{2}{c}{ B } & Std. Error & Beta & Tolerance & VIF \\
\hline \multirow{4}{*}{1} & Government Expenditure & $-2.628 \mathrm{E} 11$ & $1.072 \mathrm{E} 11$ & & & \\
& 2.072 & .229 & $\mathbf{1 . 1 3 2}$ & .006 & 158.635 \\
& M2 & -2774.866 & 2568.885 & $\mathbf{- . 1 3 5}$ & .006 & 158.613 \\
& Interest Rate & $7.736 \mathrm{E} 10$ & $3.430 \mathrm{E} 10$ & $\mathbf{. 0 2 3}$ & .995 & 1.005 \\
\hline
\end{tabular}

Based on the data from the Coefficients table, we create a model:

$$
\frac{G D P}{\text { Unemployment }}=-262.800 .000 .000+1,132 * E-0,135 * M 2+0,023 * i
$$

In the People's Republic of China, fiscal policy had the highest contribution to GDP/Unemployment of workforce ratio. It is well known that China has led uniquely restrictive fiscal policy for many decades, and as we can see, the results are impressive.

\section{RESULTS}

The results of the conducted analysis are models created on the basis of the data from the first fifteen years of the twenty-first century for four countries, one of which is Serbia. Two of the countries are developed countries, i.e. the USA and Germany, and the fourth 
one is China, the most influential country of today, even though, by GDP per capita, it is still, formally at least, a developing country.

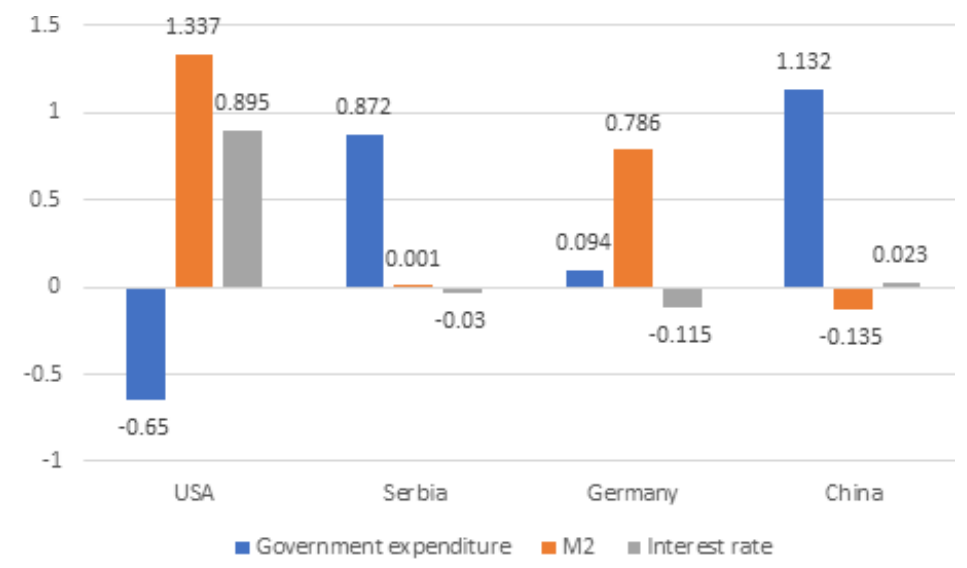

Fig. 3 Parallel view of the regression coefficients

Based on Figure 3, it is noticeable that the models for Serbia and China are mutually similar, just like the models for the USA and Germany. Namely, the representatives of the developed countries have created their economic policy in such a way that monetary policy had significantly more influence than fiscal policy did on the standard of living, measured by the GDP/Unemployment ratio. Germany and the USA have, therefore, mainly used monetary policy to stimulate economic growth, keep the unemployment down $(\mathrm{Wu}, \mathrm{Xia}$, 2016) and hold the inflation around the target level. On the other hand, in Serbia and China, the fiscal policy had the greatest influence on the dependent variable. It is well-known that China constantly used a restrictive fiscal policy for more than fifty years, and created huge amounts of the budget surplus, which was almost exclusively invested in American bonds (Li, 2008). This policy was definitely fruitful. However, it required unimaginable discipline over a very long term. It is also proven that a big part of effects of fiscal policy comes in the future. There is a study that showed the effect of the fiscal policy comes in 1-2\% after five years, $2-3 \%$ after ten years and $4 \%$ after 15 years (Gemmell, Kneller, Sanz, 2011).

\section{CONCLUSION}

Every option, therefore, has its price, and the task for the creators of an economic policy is to choose the most optimal solution in the given environment, and to ensure the implementation of the adopted measures at the institutional level in order to accomplish the planned goals. The tricky part is that it is necessary to create such a policy strategically, for a long period of time, and then only cosmetically adjust the measures to amortize the changes and ensure that the country stays on its path. This is especially difficult today, and is becoming more and more difficult every day, because of the extremely dynamic environment that we live in. Technological development is changing every single aspect of our lives on a daily basis, and it cannot be ignored. Economic policy is therefore going to have to adapt to those changes, and it is going to be a huge challenge for the future. 
It is also of great importance not to forget that measures of economic policy are not goals themselves. They are only instruments for achieving other goals, which can be summarized in maximizing the production and export. That is the only way of raising the standard of living, the ultimate economic, social and political goal for every single country in the world.

\section{REFERENCES}

Beetsma, R. \& Bovenberg, A.L. (1998). Monetary union without fiscal coordination may discipline policymakers. Journal of International Economics, 45 (2), 239-258.

Beetsma, R. \& Bovenberg, A.L. (1999). Does Monetary Unicication Lead to Excessive Debt Accumulation?. Journal of Public Economics, 74 (3), 299-325.

Campilo, M. \& Miron, J. (1997). In: Monetary Policy and Low Inflation, Christina, D. Romer and David Romer (eds.), Why Does Inflation Differ Across Countries? Chicago: The University of Chicago Press

Delong, J.B., Summers, L.H., Feldstein, M. \& Ramey, V.A. (2012). Fiscal Policy in a Depressed Economy, Brookings Papers on Economic Activity, Brookings Institution Press, Spring 2012

Gemmell, N., Kneller, R. \& Sanz, I. (2011). The Timing and Persistence of Fiscal Policy Impacts on Growth: Evidence from OECD Countries. The Economic Journal, 121 (550), F33-F58.

IMF (2000-2016). World Economic Outlook

Li, M. (2008). The Rise of China and the Demise of Capitalist World-Economy, Pluto Press, London, UK

Sargent, T.J. \& Wallace, N. (1981). Some Unpleasant Monetarist Aruthmetic. Quarterly Review, fall 1981., Reprinted in Rational Expectations and Inflation 2nd Edition NY: Harper Collins College Publishers 1993

Soldić-Aleksić, J. (2011). Primenjena Analiza Podataka [Applied Data Analysis]. Beograd: Ekonomski fakultet u Beogradu

Tanzi, V. (1977). Inflation, Lags in Collection, and the Real Value of Tax Revenue. Staff Papers, 24, March 1977.

Wu, J.S. \& Xia F.D. (2016). Measuring the Macroeconomic Impact of Monetary Policy at the Zero Lower Bound. Journal of Money, Credit and Banking, 48, (2-3), 253-291.

www.bundesbank.de

www.data.oecd.org

www.fred.stlouisfed.org

www.nbs.rs

Www.pbc.gov.cn

www.unstats.un.org

\section{RAZVOJNI EFEKTI MONETARNE I FISKALNE POLITIKE U SAVREMENIM USLOVIMA}

Jedan od najvećih problema u ekonomskoj teoriji je oduvek bila koordinacija različitih elemenata ekonomske politike, a posebno fiskalne i monetarne politike. U prošlosti je bilo ekonomskih teorija koje su favorizovale jednu u odnosu na drugu, ali u savremenim uslovima, činjenica je da je pravi odgovor samo u koordinisanom vođenju obe politike. Stoga, svaka mera monetarne politike mora biti propraćena određenom akcijom u fiskalnoj politici i obrnuto. Pitanje ostaje da li fiskalna ili monetarna politika treba da ima prioritet prilikom donošenja odluka i da li postoji šablon za kreiranje ekonomske politike. Empirijski podaci su najsvrsishodniji izvor za odgovor na ova pitanja, stoga ćemo koristiti promenjive iz četiri različite zemlje za poslednjih petnaest godina, kako bismo pokušali da pronađemo vezu između fiskalne i monetarne politike $i$ životnog standarda.

Ključne reči: Ekonomska politika, monetarna politika, fiskalna politika 